\title{
Efek Kortikosteroid Dosis Rendah terhadap Kadar Soluble Receptor for Advanced Glycation End Products Mencit Balb/C Model Sepsis
}

\author{
Diding Heri Prasetyo, ${ }^{1,2}$ Jarot Subandono, ${ }^{1}$ Siti Aisyah ${ }^{1}$ \\ ${ }^{1}$ Laboratorium Biokimia, Fakultas Kedokteran, Universitas Sebelas Maret Surakarta, ${ }^{2}$ Divisi imunologi- \\ Laboratorium Biomedik Fakultas Kedokteran, Universitas Sebelas Maret Surakarta
}

\begin{abstract}
Abstrak
Penggunaan kortikosteroid dosis rendah pada penatalaksanaan sepsis tahap awal masih diperdebatkan. Soluble receptor for advanced glycation end products (sRAGE) merupakan biomarker keparahan dan keluaran yang buruk pada sepsis. Penelitian ini bertujuan untuk menganalisis efek penggunaan kortikosteroid dosis rendah terhadap kadar sRAGE serum pada mencit Balb/C model sepsis tahap awal. Penelitian ini merupakan penelitian eksperimental laboratoris dengan sampel 30 ekor mencit Balb/C jantan dibagi menjadi kelompok kontrol, sepsis, dan sepsis+kortikosteroid dosis rendah. Penelitian dilakukan di laboratorium Histologi dan Biomedik Fakultas Kedokteran Universitas Sebelas Maret Surakarta periode Juni-Desember 2013. Untuk membuat model sepsis, hewan coba diinokulasi lipopolisakarisa/LPS (E. coli) dosis 0,1 mg/mencit secara intraperitoneal (i.p.). Kelompok mencit kontrol tidak diinokulasi selama penelitian. Kortikosteroid dosis rendah yang digunakan adalah metil prednisolon dosis 0,05 mg/mencit/hari secara i.p. Mencit kontrol tidak diinokulasi selama penelitian. Kadar sRAGE kelompok kontrol 54,29 $\pm 16,28 \mathrm{pg} / \mathrm{mL}$, sepsis 78,12 $\pm 13,38 \mathrm{pg} / \mathrm{mL}$, dan kortikosteroid dosis rendah 63,39 $\pm 11,07$ $\mathrm{pg} / \mathrm{mL}$. Kortikosteroid dosis rendah secara bermakna menurunkan kadar sRAGE $(\mathrm{p}=0,044)$ dibanding dengan kelompok sepsis. Simpulan, penggunaan kortikosteroid dosis rendah menurunkan kadar sRAGE pada hewan coba model sepsis tahap awal. [MKB. 2015;47(1):10-5]
\end{abstract}

Kata kunci: Kortikosteroid dosis rendah, sepsis, sRAGE

\section{Effects of Low-Dose Corticosteroid on Soluble Receptor for Advanced Glycation End Products in Balb/C Mice Sepsis Model}

\begin{abstract}
The use of low-dose corticosteroids in the management of early sepsis is still under debate. Soluble receptor for advanced glycation end products (sRAGE) is a biomarker of severity and poor outcome of sepsis. This study aimed to analyze the effects of the use of low-dose corticosteroids on sRAGE serum levels in Balb/C mice model of early sepsis. This study was an experimental research laboratory study with 30 male Balb/C mice which divided into control, sepsis and sepsis+low-dose corticosteroids groups. The study was conducted at Histology and Biomedical Laboratory, Faculty of Medicine, Sebelas Maret University, Surakarta, from June to December 2013. Sepsis was induced in the male Balb/C mice by inoculation with an intraperitoneally (i.p.) injection of lipopoly-saccharide/LPS (E.coli) with a dose of $0.1 \mathrm{mg} / \mathrm{mice} / \mathrm{i}$. p.for sepsis mice model. Control mice were not inoculated during the study. Lowdose corticosteroids used was methyl prednisolone at a dose of $0.05 \mathrm{mg} / \mathrm{mice} /$ day/i.p. Levels of sRAGE 54.29 \pm 16.28 $\mathrm{pg} / \mathrm{mL}$ in control group, $78.12 \pm 13.38 \mathrm{pg} / \mathrm{mL}$ in sepsis group, and $63.39 \pm 11.07 \mathrm{pg} / \mathrm{mL}$ in low-dose corticosteroids group. Low-dose corticosteroids significantly decreased sRAGE level $(\mathrm{p}=0.044)$ compared to the sepsis group. In conclusion, the use of low-dose corticosteroids reduces levels of sRAGE in early sepsis. [MKB. 2015;47(1):10-5]
\end{abstract}

Key words: Low-dose corticosteroids, sepsis, sRAGE

Korespondensi: Diding Heri Prasetyo, dr., M.Si., Lab. Biokimia Fakultas Kedokteran Universitas Sebelas Maret Surakarta. Jalan IR Sutami 36A Kentingan Jebres Surakarta, mobile 081931671212,e-mail: diding_hape@yahoo.co.id 


\section{Pendahuluan}

Sepsis adalah penyebab utama kematian pada pasien critically ill meskipun telah diberikan antibiotik dalam tatalaksana resusitasi modern. Respons septik adalah rangkaian peristiwa yang sangat kompleks, melibatkan proses inflamasi, antiinflamasi, reaksi humoral dan seluler, serta menyebabkan kelainan pada peredaran darah. Produksi sitokin-sitokin inflamasi yang berlebihan sebagai hasil aktivasi nuclear factor $\kappa-B$ (NF- $\kappa \mathrm{B}$ ) akan menyebabkan aktivasi respons sistemik berupa systemic inflammatory response syndrome (SIRS). Proses ini akan melibatkan organ paruparu, hati, ginjal, dan usus, serta organ lainnya, kemudian memengaruhi permeabilitas vaskular, fungsi jantung, serta menginduksi perubahan metabolik; sehingga terjadi apoptosis, nekrosis jaringan, multiple organ failure (MOF), disusul syok septik, serta kematian. ${ }^{1,2}$

Angka mortalitas akibat sepsis di Indonesia masih sangat tinggi. Hasil penelitian selama bulan Januari hingga Desember 2007 di Bagian Perinatal Intensive Care Unit/Neonatal Intensive Care Unit (PICU/NICU)Rumah Sakit Umum Daerah (RSUD) Dr. Moewardi Surakarta, tingkat mortalitas sepsis sebesar $50,2 \% .{ }^{3}$ Penatalaksanaan sedini-dininya pada sepsis sangat memengaruhi morbiditas dan mortalitas sepsis. Pada sepsis yang berat terjadi perubahan kompleks jaras hypothalamicpituitary-adrenal atau HPA, akan mengakibatkan penurunan produksi kortisol serta resistensi jaringan terhadap glukokortikoid yang mampu menghasilkan respons proinflamasi berlebihan, sehingga pasien sepsis berat atau syok septik diterapi menggunakan glukokortikoid eksogen. Penggunaan glukokortikoid pada pasien sepsis masih sangat kontroversial., ${ }^{2,4}$

Kortikosteroid dalam dosis tinggi ( $>300 \mathrm{mg}$ hidrokortison/hari), meskipun mempunyai efek antiinflamasi yang kuat namun menyebabkan imunosupresi yang akan membuat sel-sel sistem imunitas tidak mampu mengeliminer patogen yang masuk ke dalam tubuh. Keadaan ini akan memperburukinfeksibaikinfeksiprimer maupun sekunder. Sebaliknya, penggunaan kortikosteroid dosis rendah (300 mg hidrokortison/hari) lebih bermanfaat dalam memperbaiki fungsi adrenal pada keadaan stres dan memiliki aktivitas antiinflamasi. Studi pustaka memperlihatkan bahwa terapi kortikosteroid dosis rendah memiliki efek menguntungkan pada kematian akibat sepsis, bila dibandingkan dengan kortikosteroid dosis tinggi. Hasil lain menunjukkan bahwa penurunan respons proses inflamasi ringan yang disebabkan kortikosteroid dosis rendah pada sepsis tahap awal lebih bermanfaat, sementara penurunan respons inflamasi yang ekstensif pada pemberian kortikosteroid dosis tinggi tidak bermanfaat. Hal ini terjadi karena kortikosteroid dalam dosis tinggi akan menekan sistem imun, sedangkan pada dosis rendah dapat meningkatkan sistem imun. ${ }^{2}$ Kortikosteroid dosis rendah (1-1,5 mg/ $\mathrm{kgBB} /$ hari) menurunkan ekspresi NF- $\kappa \mathrm{B}$ dan caspase-3 dari intestinal serta mortalitas pada mencit yang diinduksi lipopolisakarida (LPS). ${ }^{5}$

Penilaian keparahan sepsis yang segera dan terapi yang tepat waktu merupakan hal yang sangat penting dalam pengobatan sepsis. Kadar dari soluble receptor for advanced glycation end products (sRAGE) merupakan petanda kerusakan seluler pada sepsis dan faktor independent yang dapat memengaruhi kemungkinan outcome yang menimbulkan kematian. Konsentrasi dari sRAGE pada pasien sepsis lebih tinggi pada pasien nonsurvival dibanding dengan survival. 6,7

Tujuan penelitian ini yaitu untuk menganalisis efek penggunaan kortikosteroid dosis rendah terhadap konsentrasi sRAGE serum pada mencit Balb/C model sepsis tahap awal.

\section{Metode}

Penelitian ini adalah penelitian eksperimental laboratoris yang menggunakan sampel sebanyak 30 ekor mencit. Kriteria inklusi yaitu mencit Balb/C jantan sehat, dengan bobot badan $\pm 15-20$ gram dan berumur 4-6 minggu yang diperoleh dari Unit Pengembangan Hewan Percobaan Universitas Setya Budi Surakarta. Mencit sehat adalah mencit dengan kondisi mata bersinar, bulu tidak kusam, aktif dan nafsu makan baik, sedangkan mencit yang mati dalam penelitian ini dieksklusi. Bahan makanan mencit digunakan pakan mencit standar.

Penentuan besar sampel dirumuskan dalam bentuk: ${ }^{8}$

$$
n=\frac{2(Z \alpha+Z \beta)^{2} \sigma^{2}}{\delta}
$$

Keterangan:

$\mathrm{n}$ = besar sampel masing-masing kelompok

$\mathrm{Z} \alpha=$ nilai standar normal, yang besarnya bergantung pada $\alpha$

$\mathrm{Z} \beta=$ nilainya bergantung pada $\beta$ yang ditentukan (berdasarkan tabel)

$\delta=$ selisih antara rata-rata variabel terapi dan kontrol yang diharapkan oleh peneliti

$\sigma=$ standar deviasi 
Hasil penghitungan dengan rumus di atas diperoleh minimal sampel untuk tiap kelompok adalah sembilan ekor mencit, dalam penelitian ini mempergunakan sepuluh ekor mencit untuk tiap kelompok sesuai persetujuan Komite Etik Fakultas Kedokteran, Universitas Sebelas Maret Surakarta.

Penelitian ini dilaksanakan di Laboratorium Histologi dan Biomedik Fakultas Kedokteran Universitas Sebelas Maret Surakarta selama bulan Juni-Desember 2013. Hewan coba yang telah diadaptasikan selama satu minggu dibagi menjadi tiga kelompok, setiap kelompok terdiri atas 10 ekor. Kelompok I tanpa diberi perlakuan (kontrol), sedangkan kelompok II mencit model sepsis (perlakuan) dan kelompok III mencit model sepsis yang diberi kortikosteroid dosis rendah (terapi).

Kortikosteroid yang digunakan adalah metil prednisolon dengan dosis $0,05 \mathrm{mg} /$ mencit dua kali sehari secara intraperitoneal (i.p.). Untuk membuat model sepsis, hewan coba diinokulasi LPS (E. coli) dari Sigma Aldrich (Deisenhofen, Germany) dengan dosis $0,1 \mathrm{mg} / \mathrm{mencit} /$ i.p. ${ }^{9}$ Pada hari ke-5 mencit dikorbankan. Darah dari pungsi jantung diencerkan memakai ethylene diamine tetraacetic acid (EDTA) dengan perbandingan
EDTA:darah=1,5:1; lalu dilakukan sentrifugasi dengan kecepatan $3.000 \mathrm{rpm}$ pada suhu $37^{\circ} \mathrm{C}$ selama 15 menit. Pengukuran kadar sRAGE dilakukan pada serum hasil koleksi itu dengan memakai teknik enzyme-linked immunosorbent assay (ELISA) kit sesuai dengan protokol yang sudah dianjurkan oleh pabriknya (Pharmingen, San Diego, California, USA). Data yang diperoleh dianalisis dengan uji ANOVA atau alternatifnya dengan tingkat signifikansi $\mathrm{p}<0,05$.

\section{Hasil}

Hasil penelitian memperlihatkan kadar sRAGE kelompokmencit kontrol adalah $54,29 \pm 16,28 \mathrm{pg} /$ mL. Injeksi LPS dosis $0,1 \mathrm{mg} / \mathrm{mencit} / \mathrm{i} . \mathrm{p}$., secara bermakna $(p=0,002)$ meningkatkan kadar sRAGE pada kelompok mencit sepsis yaitu 78,12 $\pm 13,38$ $\mathrm{pg} / \mathrm{mL}$. Pemberian metil prednisolon dosis 0,05 $\mathrm{mg} /$ mencit dua kali sehari i.p. pada mencit model sepsis secara bermakna $(\mathrm{p}=0,044)$ menurunkan kadar sRAGE menjadi 63,39 $\pm 11,07 \mathrm{pg} / \mathrm{mL}$.

Variabel yang diteliti adalah kadar sRAGE berupa data kuantitatif, langkah pertama menguji beda k rata-rata pada kelompok sepsis awal, yaitu melibatkan kelompok kontrol, sepsis awal,

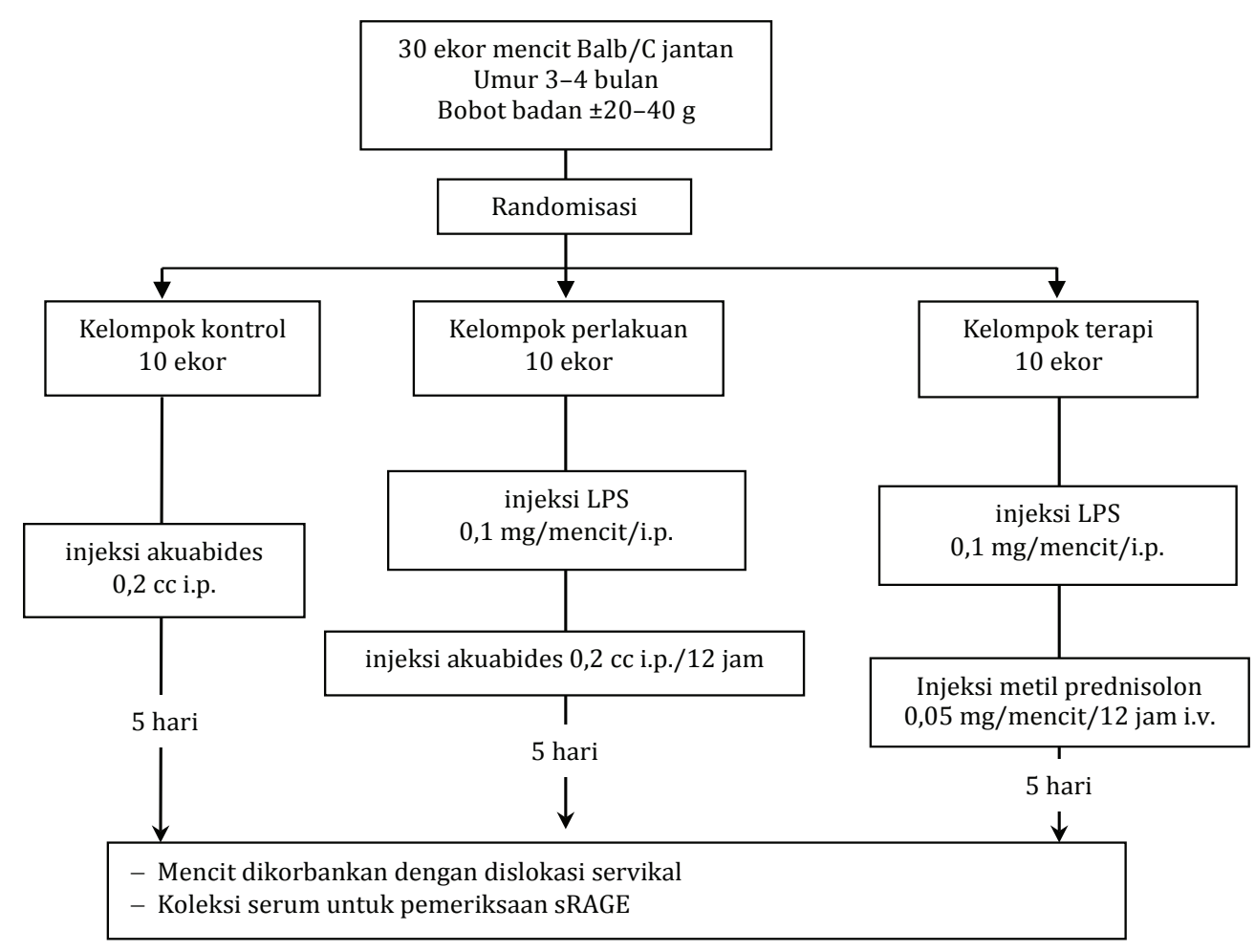

\section{Gambar 1 Diagram Cara Penelitian}


Diding H.: Efek Kortikosteroid Dosis Rendah terhadap Kadar Soluble Receptor for Advanced Glycation End Products

Tabel 1 Variasi atau Perbedaan Tiga Kadar sRAGE Rata-rata Menurut Kelompok Sampel

\begin{tabular}{cccccccc}
\hline \multicolumn{2}{c}{ Kontrol } & \multicolumn{2}{c}{ Perlakuan } & \multicolumn{2}{c}{ Terapi } & \multicolumn{2}{c}{ Hasil ANOVA } \\
\hline Rata-rata & Std & Rata-rata & Std & Rata-rata & Std & Nilai F & Sig \\
\hline 54,29 & 16,28 & 78,12 & 13,38 & 63,39 & 11,07 & 6,127 & $0,008^{*}$ \\
\hline
\end{tabular}

dan sepsis awal+steroid dosis rendah. Distribusi data variabel sRAGE masing-masing kelompok di atas sudah diuji dan hasilnya berdistribusi normal, maka pengujian variasi atau beda tiga rata-rata menggunakan ANOVA atau uji F.

Tabel 1 menunjukkan hasil uji ANOVA untuk variabel sRAGE pada kelompok sepsis awal. Hasil analisis beda tiga rata-rata di atas menghasilkan nilai $\mathrm{F}$ hitung=6,127 dengan tingkat signifikansi sebesar 0,008 yang berarti beda tiga rata-rata itu signifikan pada derajat signifikansi $(\mathrm{p}<0,05)$. Hal itu berarti beda sRAGE rata-rata pada kelompok kontrol, sepsis awal, dan sepsis awal+steroid dosis rendah berbeda. Jika dibandingkan dengan sRAGE rata-rata kelompok kontrol, kelompok sepsis awal memiliki kecenderungan sRAGE ratarata meningkat, selanjutnya dapat diturunkan dengan pemberian steroid dosis rendah.

Hasil penelusuran beda dua rata-rata dari masing-masing kelompok dapat dijelaskan pada Tabel 2. Hasil analisis beda dua rata-rata sampel independen dengan menggunakan penelusuran Post Hoc test di atas menunjukkan bahwa uji terhadap variabel kadar sRAGE antara kelompok kontrol dan sepsis awal signifikan pada derajat signifikansi sebesar 0,002 persen $(p<0,05)$. Hal itu dapat dikatakan bahwa pada mencit sepsis awal kadar sRAGE meningkat signifikan. Setelah diberikan steroid dosis rendah maka kadar sRAGE mengalami penurunan, sehingga beda dua rata-rata kelompok sepsis awal dan sepsis awal+steroid dosis rendah berbeda secara

\begin{tabular}{ccc}
$\begin{array}{c}\text { Tabel } 2 \text { Penelusuran Beda Dua Rata-rata } \\
\text { Kadar sRAGE antara Kelompok } \\
\text { Sampel }\end{array}$ & \\
\hline $\begin{array}{c}\text { Penelusuran Beda } \\
\text { 2 Rata-rata }\end{array}$ & $\begin{array}{c}\text { Beda } \\
\text { Rata-rata }\end{array}$ & Signifikansi \\
\hline Kontrol- Perlakuan & $-23,83$ & $0,002^{*}$ \\
Kontrol - Terapi & $-9,11$ & 0,199 \\
Perlakuan-Terapi & 14,73 & $0,044^{*}$ \\
\hline
\end{tabular}

Sumber: Data Primer 2014, diolah

Keterangan: *) Signifikan pada derajat signifikansi 5 persen signifikan dengan tingkat signifikansi sebesar $0,044(p<0,05)$. Hasil ini dapat disimpulkan bahwa pemberian kortikosteroid dosis rendah signifikan menurunkan kadar sRAGE pada sepsis tahap awal.

\section{Pembahasan}

Sepsis merupakan suatu sindrom klinis sebagai manifestasi proses inflamasi imunologik yang terjadi karena respons tubuh (imunitas) yang berlebihan terhadap produk mikroorganisme. Selama sepsis berat terjadi kegagalan migrasi neutrofil ke tempat infeksi yang memberikan kontribusi penyebaran infeksi mengakibatkan meningkatnya potensi mortalitas. Penurunan proses migrasi neutrofil berhubungan dengan penurunan rolling dan adhesi neutrofil pada sel endotel, menyebabkan kegagalan pemberesan bakteri ke tempat infeksi, meningkatkan jumlah bakteremia, dan juga meninggikan kadar sitokin atau kemokin serta mortalitas. ${ }^{10}$

Penggunaan mencit jantan pada penelitian ini mengurangi efek hormonal yang ditimbulkan dari progesteron yang dihasilkan mencit betina. Progesteron merupakan zat perantara metabolik dalam proses produksisteroid endogen, termasuk hormon seks dan kortikosteroid. Penggunaan kortikosteroid dosis rendah pada sepsis tahap awal masih diperdebatkan, dalam keadaan syok septik (sepsis tahap lanjut), efek kortikosteroid terhadap imunitas bergantung pada kondisi sebelumnya, besar dosis serta waktu pemberian. Bukti yang menguntungkan efek kortikosteroid terhadap infeksi adalah penurunan petanda inflamasi. Kortikosteroid dalam dosis rendah diketahui memiliki efek antiinflamasi spektrum luas tanpa mengakibatkan penekanan sistem imun/imunoparalisis, merupakan suatu pilihan untuk mendapatkan stabilitas hemodinamik. Titik tangkap pemberian kortikosteroid dalam dosis rendah pada sepsis adalah mengurangi respons inflamasi sistemik sebagai vasopresor, menghambat produksi sitokin proinflamasi dan mediator inflamasi seperti siklooksigenase-2, 
serta menurunkan adhesi leukosit ke endotel. Kortikosteroid mampu memblok jalur inflamasi melalui sejumlah jalur, antara lain menghambat produksi prostaglandin melalui induksi dan aktivasi annexin-1, dan induksi mitogen-activated protein kinases (MAPK) fosfatase-1, sehingga menekan transkripsi siklooksigenase-2..$^{11,12}$

Peran NF- $\kappa$ B ini mengindikasikan terdapat fungsi yang saling berlawanan. Di sisi lain, NF$\kappa \mathrm{B}$ penting untuk pengaktifan gen proinflamasi yang penting untuk perbaikan inflamasi dan perlindungan pada apoptosis. Pengaktifan NF$\kappa \mathrm{B}$ in vivo yang berlebihan akan menyebabkan kematian, hal ini disebabkan pada tingkatan seluler pengaktifan NF- $\kappa$ B yang berlebihan akan menghambat proses aktivasi respons imun dan peningkatan kepekaan untuk apoptosis..$^{13}$ Ikatan pathogen-associated molecular patterns (PAMPs) dari mikroorganisme dengan pattern recognition receptors (PRRs) pada permukaan sel sistem imunitas tubuh akan memicu pelepasan sitokin melalui induksi dari faktor transkripsi (Nf- $\mathrm{kB}$ ). Kondisi ini akan meningkatkan ekspresi RAGE, pada gilirannya menghasilkan inflamasi. RAGE memiliki bentuk sekretorik yang disebut sebagai RAGE terlarut (sRAGE). ${ }^{14}$ Kortikosteroid dosis rendah $(1-1,5 \mathrm{mg} / \mathrm{kgBB} /$ hari) terlihat mampu menurunkan ekspresi NF- $\kappa$ B serta caspase-3 dari intestinal sehingga menurunkan mortalitas pada mencit yang diinduksi LPS. Kortikosteroid dosis rendah mampu menghambat aktivasi NF$\kappa \mathrm{B}$ sehingga akan menurunkan produksi dan pelepasan sRAGE. $^{5}$ Keadaan ini akan mampu menurunkan derajat inflamasi pada sepsis.

Hasil penelitian ini sejalan dengan hasil penelitian yang dilakukan oleh van den Berg dkk., ${ }^{15}$ terlihat bahwa pemberian deksametason dosis rendah sebesar $0,05 \mathrm{mg} / \mathrm{kgBB}$ ternyata mampu meningkatkan survival, namun dalam menurunkan parameter inflamasi seperti kadar sitokin dan molekul adhesi dalam plasma, paru, ginjal maupun hati tidak begitu kuat. Pemberian deksametason dalam dosis sedang $0,25 \mathrm{mg} / \mathrm{kgBB}$ ataupun deksametason dosis tinggi 2,5 mg/kgBB secara bermakna menurunkan respons inflamasi tetapi tidak mempunyai efek untuk survival. Pemberian deksametason dosis rendah secara bermakna mampu menghambat bakteremia, sedangkan dalam dosis sedang dan besar tidak menghambat bakteremia. Receptor for advanced glycation end products (RAGE) terlarut dalam bentuk endogenous secretory RAGE (esRAGE) dan bentuk cleaved RAGE (cRAGE) mempunyai afinitas mirip dengan reseptor yang terikat di membran. Dengan demikian, sRAGE dipercaya berfungsi sebagai reseptor umpan yang akan membatasi konsentrasi ligan yang tersedia. Ternyata sRAGE diketahui langsung berikatan dengan reseptor-reseptor membran untuk dapat mencegah homodimerisasi yang diinduksi ligan, penting untuk inisiasi pensinyalan selanjutnya. ${ }^{16}$ sehingga peningkatan kadar sRAGE merupakan prediktor dari survival yang buruk pada pasien sepsis. ${ }^{14}$

Simpulan, penggunaan kortikosteroid dosis rendah menurunkan kadar sRAGE serum pada hewan coba model sepsis tahap awal.

\section{Ucapan Terima kasih}

Kepada Direktorat Jenderal Pendidikan Tinggi, Departemen Pendidikan Nasional Republik Indonesia yang telah mendanai penelitian ini dalam program Dana BOPTN Universitas Sebelas Maret Nomor 165/UN27.11/PN/2013 Tanggal 10 Juni 2013.

\section{Daftar Pustaka}

1. Bosmann M, Ward PA. The inflammatory response in sepsis. Trends Immunol. 2012;S1471-4906(12):00162-7.

2. Guntur AH. Imunologi, diagnosis dan penatalaksanaan sepsis. Surakarta: UNS Press; 2001.

3. Pudjiastuti. Imunoglobulin intravena pada anak dan bayi dengan sepsis. Kumpulan makalah. National Symposium: the $2^{\text {nd }}$ Indonesian Sepsis Forum. Surakarta, March 7-9 $9^{\text {th }} .2008$.

4. Marik PE. Glucocorticoids in sepsis: dissecting facts from fiction. Crit Care. 2011; 15(3):158.

5. Guntur HA, Diding HP, Pohan HT, Widodo D. Effect of low-dose steroid on NF- $\kappa B$ and caspase-3 intestinal expression in a sepsis mouse model. Crit Care. 2011;15 (Suppl 3):44.

6. Narvaez-Rivera RM, Rendon A, SalinasCarmona MC, Rosas-Taraco AG. Soluble RAGE as a severity marker in community acquired pneumonia associated sepsis. BMC Infect Dis. 2012;12:15.

7. Bopp C, Hofer S, Weitz J, Bierhaus A, Nawroth PP, Martin E, dkk. sRAGE is elevated in septic patients and associated with patients outcome. J Surg Res. 2008;147(1):79-83.

8. Dahlan MS. Besar sampel dan cara pengambilan sampel dalam penelitian kedokteran dan kesehatan. Edisi ke-2. 
Diding H.: Efek Kortikosteroid Dosis Rendah terhadap Kadar Soluble Receptor for Advanced Glycation End Products

Jakarta: Salemba Medika; 2009.

9. Wang XL, Li Y, Kuang JS, Zhao Y, Liu P. Increased heat shock protein 70 expression in the pancreas of rats with endotoxic shock. World J Gastroenterol. 2006;12(5):780-3.

10. Treacher DF, Brown KA. The basic science of sepsis. Surgery. 2009;27(11):465-9.

11. de Kruif MD, Lemaire LC, Giebelen IA, Struck J, Morgenthaler NG, Papassotiriou J, dkk. The influence of corticosteroids on the release of novel biomarkers in human endotoxemia. Intensive Care Med. 2008;34(3):518-22.

12. Rhen T, Cidlowski JA. Antiinflammatory action of glucocorticoids-new mechanisms for old drugs. N Engl J Med. 2005;353(16): 1711-23.

13. Salminena A, Huuskonena J, Ojala J, Kauppinena A, Kaarniranta K, Suuronen T. Activation of innate immunity system during aging: NF-kB signaling is the molecular culprit of inflamm-aging. Ageing Research Rev. 2008;7(2):83-105.

14. Narvaez-Rivera RM, Rendon A, SalinasCarmona MC, Rosas-Taraco AG. Soluble RAGE as a severity marker in community acquired pneumonia associated sepsis. BMC Infect Dis. 2012;12:15.

15. van den Berg JW, van der Zee M, de Bruin RW, van Holten-Neelen C, Bastiaans J, Nagtzaam NM, dkk. Mild versus strong antiinflammatory therapy during early sepsis in mice: a matter of life and death. Crit Care Med. 2011;39(6):1275-81.

16. Zong $\mathrm{H}$, Madden A, Ward M, Mooney MH, Elliott CT, Stitt AW. Homodimerization is essential for the receptor for advanced glycation end products (RAGE)-mediated signal transduction. J Biol Chem. 2010; 285(30):23137-46. 